\title{
Effects of natural light on nitrogen cycling rates in the Mississippi River plume
}

\author{
Wayne S. Gardner' and Joann F. Cavaletto \\ NOAA Great Lakes Environmental Research Laboratory, 2205 Commonwealth Blvd., Ann Arbor, Michigan 48105
}

James B. Cotner

Department of Wildlife and Fisheries Sciences, Texas A\&M University, College Station, Texas 77843

\section{Jeffrey R. Johnson}

Cooperative Institute for Limnology and Ecosystem Research, University of Michigan, Ann Arbor, Michigan 48105

\begin{abstract}
Isotope-dilution experiments with ${ }^{15} \mathrm{NH}_{4}{ }^{+}$were conducted on near-surface water samples in the Mississippi River plume during May 1992 and July 1993 to quantify community cycling rates for ammonium and determine whether regeneration rates are enhanced by light. Experiments done under natural light in May showed ranges of potential uptake and regeneration rates of $0-0.4 \mu \mathrm{M} \mathrm{h}^{-1}$ and $0-0.18 \mu \mathrm{M} \mathrm{h}^{-1}$. Samples collected offshore from the Atchafalaya River and the Southwest Pass of the Mississippi River in July yielded potential uptake rates of $0.4-1.8 \mu \mathrm{M} \mathrm{h} \mathrm{h}^{-1}$ under natural light vs. $0-0.45 \mu \mathrm{M} \mathrm{h}^{-1}$ in the dark. Ammonium regeneration rates ranged from 0.08 to $0.75 \mu \mathrm{M}$ $\mathrm{h}^{-1}$ in the light and from 0.02 to $0.3 \mu \mathrm{M} \mathrm{h}^{-1}$ in the dark. The observed light/dark regeneration-rate differences imply a close coupling between phytoplankton production and ammonium regeneration. The ratio of bacterial cellspecific regeneration to uptake rates increased in the outer regions of the plume, indicating a changing contribution of bacterial-sized organisms to nitrogen cycling processes in different regions of the plume.
\end{abstract}

Water-column nutrient recycling by bacteria and other heterotrophic organisms is a dominant process supplying nutrients to phytoplankton in photic zones of both marine and frcshwater ecosystems. The contribution of bacteria, relative to protozoa and zooplankton, in nutrient regeneration depends on the chemical composition and supply rates of available bacterial substrates, temperature, and food-web structure and dynamics (Haga et al. 1995; Miller et al. 1995). Studies with isolated dissolved organic matter (DOM) indicate that high-molecular-weight DOM has a high $C: N$ ratio (Benner et al. 1992) and is more biologically reactive than is low-molecular-weight DOM (Amon and Benner 1994). However, other studies indicate that dissolved organic nitrogen (DON) is actively released during photosynthesis (Bronk et al. 1994) and that low-molecular-weight compounds such as dissolved free amino acids are major substrates for bacteria. These compounds may be assimilated by bacteria and recycled by microbial food-web organisms on relatively short time scales, particularly in warm waters where conditions are optimal for microbial activity (Gardner et al. 1996).

A relatively direct relationship between phytoplankton production and nitrogen recycling rates is suggested by depth profiles of nutrient regeneration rates. For example, in Gulf of Mexico Mississippi River plume waters, ammonium

\footnotetext{
${ }^{1}$ Present address: Marine Science Institute, University of Texas at Austin, Port Aransas, Texas 78373.

\section{Acknowledgments}

We thank the crew of the RV Longhorn for help during the cruises, D. Dong for in situ fluorescence data, D. Stockwell and D. Pakulski for chlorophyll data, C. Darnell for technical and editorial support, R. Benner and B. Eadie for DOC discussions, and P. Lavrentyev and $\mathrm{H}$. Bootsma for suggestions on the manuscript.

This paper is GLERL contribution 995.
}

regeneration rates, amino acid turnover rates, and bacterial growth rates were highest in surface water $(0-1 \mathrm{~m})$ but very low at depths as shallow as $4 \mathrm{~m}$ (Chin-Leo and Benner 1992; Gardner et al. 1993). Studies in the northern Gulf of Mexico (Coffin et al. 1994) and other regions (e.g. Cole et al. 1982) imply a close relationship between phytoplankton production and the dynamics of bacteria and DOM.

The above observations suggest that pelagic nitrogen recycling rates in the Mississippi River plume depend directly on production rates of labile particulate nitrogen or DON by phytoplankton. Because phytoplankton produce more labile organic nitrogen under natural light than in the dark, we hypothesized that ammonium regeneration rates may also be higher in the light than in the dark. A previous comparison of regeneration rates in the Delaware River did not reveal consistent differences between light and dark incubations, probably because of problems in obtaining precise remineralization rates (Lipschultz et al. 1986). The links between phytoplankton and bacteria may be less direct in some turbid riverine regions, where allochthonous organic material is available (Finlay et al. 1991; Carlsson et al. 1995), than in regions where phytoplankton are the major source of available organic substrates.

We conducted isotope-dilution experiments with ${ }^{15} \mathrm{NH}_{4}^{+}$ under natural light in May 1992 and under both natural light and dark conditions in July 1993 to assess nitrogen cycling rates in Mississippi River plume surface waters. Rate measurement precision was improved over previous studies by directly measuring isotope ratios in incubation-water filtrates with high-performance liquid chromatography (HPLC).

\section{Methods}

Study sites and chlorophyll measurements-Experiments were conducted onboard the RV Longhorn in the northern 
Table 1. Sampling dates, locations, salinities, surface-water temperatures, and incubation times $\left(T_{0}\right.$ to $\left.T_{1}\right)$ used to calculate nitrogen cycling rates for stations in the Mississippi River plume in May 1992 and in the Atchafalaya and Mississippi River plumes in July 1993.

\begin{tabular}{|c|c|c|c|c|c|}
\hline Sta. & Date & Location & $\begin{array}{c}\text { Salinity } \\
(\% o)\end{array}$ & $\begin{array}{c}\text { Temp. } \\
\left({ }^{\circ} \mathrm{C}\right)\end{array}$ & $\begin{array}{c}\text { Incub. } \\
\text { time } \\
\text { (h) }\end{array}$ \\
\hline \multicolumn{6}{|c|}{ Southwest Pass } \\
\hline 1 & 5 May & $28^{\circ} 52.08^{\prime} \mathrm{N}, 89^{\circ} 28.31^{\prime} \mathrm{W}$ & 10 & 22 & 2.8 \\
\hline 2 & 6 May & $28^{\circ} 43.45^{\prime} \mathrm{N}, 89^{\circ} 28.17^{\prime} \mathrm{W}$ & 18 & 17 & 7.3 \\
\hline 3 & 7 May & $29^{\circ} 10.18^{\prime} \mathrm{N}, 89^{\circ} 15.67^{\prime} \mathrm{W}$ & 0 & 19 & 5.7 \\
\hline 4 & 8 May & $28^{\circ} 46.50^{\prime} \mathrm{N}, 89^{\circ} 30.33^{\prime} \mathrm{W}$ & 28 & 21 & 5.3 \\
\hline 5 & 9 May & $28^{\circ} 51.33^{\prime} \mathrm{N}, 89^{\circ} 31.61^{\prime} \mathrm{W}$ & 18 & 20 & 6.3 \\
\hline 6 & 10 May & $27^{\circ} 34.72^{\prime} \mathrm{N}, 89^{\circ} 56.15^{\prime} \mathrm{W}$ & 36 & 23 & 12.0 \\
\hline 7 & 10 May & $28^{\circ} 51.60^{\prime} \mathrm{N}, 89^{\circ} 34.41^{\prime} \mathrm{W}$ & 8 & 22 & 13.3 \\
\hline 8 & 11 May & $28^{\circ} 44.05^{\prime} \mathrm{N}, 90^{\circ} 05.46^{\prime} \mathrm{W}$ & 32 & 22 & 3.5 \\
\hline \multicolumn{6}{|c|}{ Atchafalaya } \\
\hline 1 & 15 July & $29^{\circ} 10.30^{\prime} \mathrm{N}, 91^{\circ} 45.90^{\prime} \mathrm{W}$ & 15 & 29 & 1.0 \\
\hline 2 & 15 July & $29^{\circ} 16.30^{\prime} \mathrm{N}, 91^{\circ} 44.20^{\prime} \mathrm{W}$ & 8 & 30 & 1.4 \\
\hline 8 & 22 July & $29^{\circ} 10.70^{\prime} \mathrm{N}, 91^{\circ} 33.40^{\prime} \mathrm{W}$ & 10 & 31 & 2.7 \\
\hline 9 & 23 July & $28^{\circ} 49.50^{\prime} \mathrm{N}, 92^{\circ} 05.84^{\prime} \mathrm{W}$ & 24 & 30 & 3.5 \\
\hline \multicolumn{6}{|c|}{ Southwest Pass } \\
\hline 3 & 16 July & $29^{\circ} 00.12^{\prime} \mathrm{N}, 89^{\circ} 49.45^{\prime} \mathrm{W}$ & 14 & 29 & 4.7 \\
\hline 4 & 17 July & $28^{\circ} 53.70^{\prime} \mathrm{N}, 89^{\circ} 26.30^{\prime} \mathrm{W}$ & 0 & 30 & 3.4 \\
\hline 5 & 17 July & $28^{\circ} 52.60^{\prime} \mathrm{N}, 89^{\circ} 27.40^{\prime} \mathrm{W}$ & 15 & 30 & 2.4 \\
\hline 6 & 18 July & $28^{\circ} 53.40^{\prime} \mathrm{N}, 89^{\circ} 26.00^{\prime} \mathrm{W}$ & 7 & 28 & 3.2 \\
\hline 7 & 19 July & $28^{\circ} 47.00^{\prime} \mathrm{N}, 90^{\circ} 04.50^{\prime} \mathrm{W}$ & 23 & 30 & 2.5 \\
\hline
\end{tabular}

Gulf of Mexico in the Mississippi River plume in May 1992 and July 1993. Plume surface-water temperatures ranged from 17 to $23^{\circ} \mathrm{C}$ in May and from 28 to $31^{\circ} \mathrm{C}$ in July (Table 1). May samples were collected in the plume offshore from the Southwest Pass of the Mississippi River, whereas July samples were collected from salinity transects extending offshore from Atchafalaya Bay and southwesterly from the Southwest Pass (Table 1). Both of these regions receive large inputs of water (with associated nutrients) from the Mississippi River. The Atchafalaya River flows through regions of shallow wetlands and Atchafalaya Bay. In this system, a part of the riverine nitrate may be transformed to reduced forms (organic nitrogen or ammonium) or denitrified before it is delivered into the Gulf of Mexico via the Atchafalaya River/ Bay system. The Southwest Pass delivers Mississippi River water more directly into the Gulf of Mexico. Biological modification of nutrients in the river is probably minimal in this "pipeline" system. High turbidity prevents significant primary production (Lohrenz et al. 1990) and associated heterotrophic processes from occurring in zero-salinity river outflow regions of the plume (Gardner et al. 1994).

Relative chlorophyll concentrations across the plume in 1993 were estimated from in situ fluorescence measurements (Fig. 1) obtained with a Sea-Bird Electronics 911 Plus CTD system equipped with a Sea Tech fluorometer (excitation wavelength of $425 \mathrm{~nm}$, emission wavelength $685 \mathrm{~nm}$ ). Chlorophyll data from selected stations during the same cruise (Fig. 1) were kindly provided by D. Stockwell and D. Pakulski.

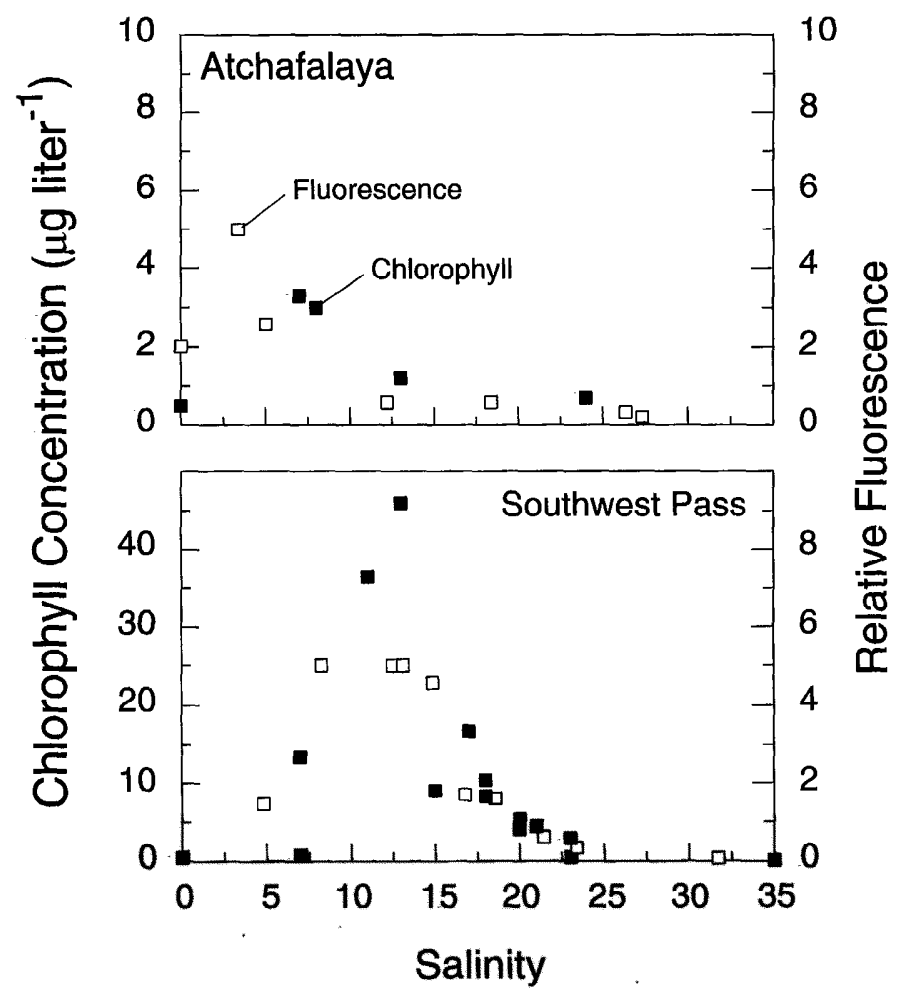

Fig. 1. Chlorophyll concentrations and relative in situ fluorescence (reflecting relative chlorophyll concentrations in arbitrary units) vs. salinity for the Atchafalaya and Southwest Pass transects of the July 1993 cruise. Note that the fluorescence readings apparently reached saturation at $\sim 5.2$ units.

Nitrogen transformation experiments-Isotope-dilution experiments were conducted on near-surface (0-1-m depth) water. For each experiment, subsamples of water $(70 \mathrm{ml}$ each) wese dispensed into six 75-ml tissue culture bottles, and ${ }^{15} \mathrm{NH}_{4}{ }^{+}$was added to give a final ${ }^{15} \mathrm{NH}_{4}{ }^{+}$concentration of $4 \mu \mathrm{M}$. After mixing and initial sampling, the bottles were placed in deck-top incubators held at in situ temperatures under natural light conditions (at $50 \%$ of surface light intensity; both cruises) and in the dark (aluminum foil wrap; July experiments). Thus, the experimental design in July included balanced light and dark treatments with added ${ }^{15} \mathrm{NH}_{4}{ }^{+}$. Each treatment was conducted in triplicate bottles for experimental replication.

Samples for measuring concentrations and isotope ratios (atom \% ${ }^{15} \mathrm{~N}$ enrichment) for ammonium were collected a few minutes after addition of the labeled compounds and again after measured incubation intervals. About $10 \mathrm{ml}$ of water was removed from each treatment and passed through a $0.2-\mu \mathrm{m}$ pore-size nylon filter $(25-\mathrm{mm}$ diam; vacuum of $\sim 150 \mathrm{~mm} \mathrm{Hg}$ ). The first $3 \mathrm{ml}$ rinsed the filter and was discarded. The next $7 \mathrm{ml}$ of filtrate was collected in a clean 8-ml vial (Wheaton No. 224884) for analysis. Ammonium concentrations were measured onboard by HPLC (Gardner and St. John 1991). The remaining filtrate was frozen for later isotope ratio analysis by HPLC (Gardner et al. 1995a). In this cation-exchange technique, atom $\%{ }^{15} \mathrm{~N}$ enrichment of ammonium is determined directly in the filtrate by quan- 
tifying the shift in ammonium retention time, caused by the presence of ${ }^{15} \mathrm{NH}_{4}{ }^{+}$, relative to that for an internal ammonium standard. When retention times are determined from the median areas of the peaks, the relationship between retention time shift and atom $\%{ }^{15} \mathrm{~N}$ enrichment over the range of isotope ratios is linear ( $r>0.995$; Gardner et al. 1995a).

Community ammonium regeneration and potential uptake rates in the bottles treated with ${ }^{15} \mathrm{NH}_{4}{ }^{+}$were calculated from changes in dissolved ammonium concentrations and isotope ratios over time with the Blackburn model (Blackburn 1979). The SEs for uptake and regeneration results from triplicate bottle experiments receiving the same treatments were usually $< \pm 0.03 \mu \mathrm{M} \mathrm{h}^{-1}$ (see results), a value that also defined the approximate detection limit of the method. Incorporation rates are expressed as potential uptake rates because uptake rates may be proportional to ammonium concentration and ammonium was added at higher than ambient levels. Regeneration rates should be less sensitive to ammonium concentrations than are uptake rates over short incubation periods but may also be enhanced by ammonium additions if phytoplankton production and associated DON release are stimulated by ammonium additions (Selmer 1988).

Experiments with bacterial-sized particle additions-In these experiments, we increased the concentrations of bacterial-sized particles (including bacteria and some cyanobacteria; Cotner and Gardner 1993) relative to the abundances of other organisms. Abundances were manipulated by adding $0-20 \mathrm{ml}$ of concentrated particles to whole seawater to give a final volume of $60 \mathrm{ml}$. Bacterial abundances in the various treatments were estimated from the volume of the two water fractions used to make up each treatment (whole seawater and concentrated particles) and acridine orange direct counts (Hobbie et al. 1977) of duplicate samples of these fractions. Before concentrating particles, seawater was prefiltered (vacuum of $<200 \mathrm{~mm} \mathrm{Hg}$ ) through a nominal $1-\mu \mathrm{m}$ pore-size polycarbonate capsulc filter (Nuclepore). The particles were then concentrated in a recirculating tangential flow system with either a 50,000- $M_{\mathrm{r}}$ (May 1992; A/G Technology) or a $0.1-\mu \mathrm{m}$ pore-size (July 1993; Amicon) cutoff hollow-fiber filter. In May, particles were concentrated $\sim 10-$ fold with a peristaltic pump, the hollow-fiber filter, and a glass reservoir. In July, particles were concentrated $\sim 30$-fold with an Amicon DC 10L system. After addition of concentrate to incubation bottles, labeled ammonium was added to respective duplicate bottles to give an ${ }^{15} \mathrm{NH}_{4}{ }^{+}$concentration of $4 \mu \mathrm{M}$, and isotope dilution experiments were conducted under natural light as described above for unfiltered seawater. When observed, increased ammonium regeneration rates corresponding to increased numbers of bacteria were assumed to be caused directly by bacteria (or similar-sized organisms), whereas the absence of increased ammonium regeneration rates with increased particle density was assumed to indicate that most of the ammonium regeneration was done by organisms $>1 \mu \mathrm{m}$.

\section{Results}

Chlorophyll and ammonium concentrations-Relative chlorophyll concentrations in July, as indicated by in situ

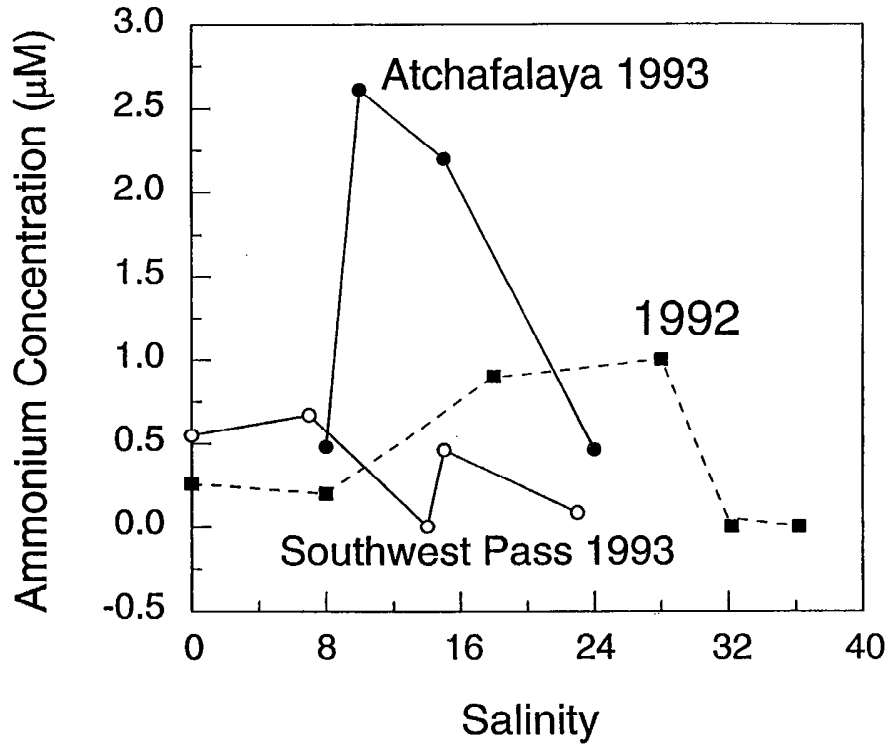

Fig. 2. Ammonium concentrations vs. salinity for the Mississippi River plume (Southwest Pass region) in May 1992 and the Atchafalaya and Southwest Pass transects in July 1993.

fluorescence, peaked at salinities between 7 and $20 \%$ in samples from the Southwest Pass transect and at $\sim 3 \%$ in the Atchafalaya transect (Fig. 1). Measured chlorophyll concentrations showed similar patterns but had less spatial resolution in the Atchafalaya transect (Fig. 1). Ambient ammonium concentrations in May 1992 and July 1993 ranged from 0 to $1.0 \mu \mathrm{M}$ in the Southwest Pass transect and from $\sim 0.5$ to $2.6 \mu \mathrm{M}$ in the Atchafalaya transect (Fig. 2). Concentrations of ammonium peaked at midsalinities in the Atchafalaya transect but not as sharply in the Southwest Pass transect.

Nitrogen cycling rates-Nitrogen cycling rates peaked in midsalinity waters in both May 1992 and July 1993, but the salinity of peak-cycling rates in the Southwest Pass region was higher in May (28\%o) than in July (15\%o) (Figs. 3, 4). Following the trends for chlorophyll concentrations, potential uptake rates and regeneration rates for ammonium under natural light in July peaked at the 15\%o station in the Southwest Pass transect (Fig. 4). In the Atchafalaya transect, nitrogen cycling-rate experiments were conducted at stations offshore (higher salinities) from the peak-chlorophyll station, as indicated by in situ fluorescence (Fig. 1).

The range in regeneration rates $\left(\sim 0.06-0.75 \mu \mathrm{M} \mathrm{h}^{-1}\right)$ measured under natural light in July 1993 was comparable to but greater than that previously reported for samples collected from the same region in September 1991 and analyzed by the same isotope-dilution technique $\left(0-0.4 \mu \mathrm{M} \mathrm{h}^{-1}\right.$; Cotner and Gardner 1993). However, midsalinity rates were much higher than those observed from dark incubations in February 1991 ( $<0.05 \mu \mathrm{M} \mathrm{h}^{-1}$; Cotner and Gardner 1993). Rates measured in the May 1992 cruise under natural light $\left(0-0.18 \mu \mathrm{M} \mathrm{h}^{-1}\right)$ were intermediate between these extremes (Fig. 3).

The ${ }^{15} \mathrm{~N}$-isotope-dilution experiments in July were con- 


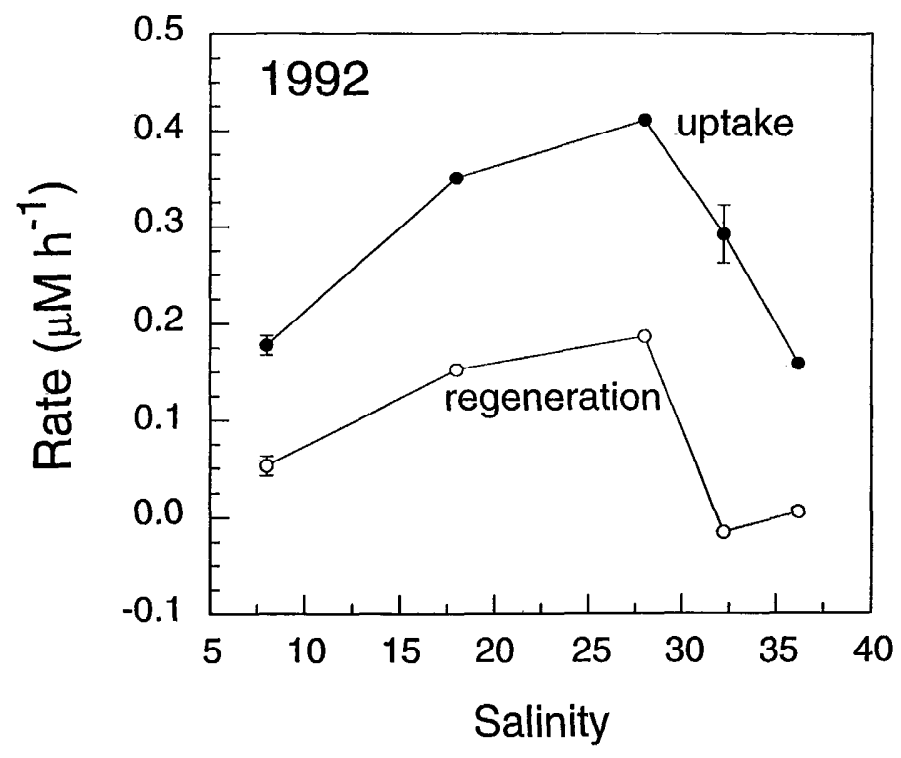

Fig. 3. Potential uptake and regeneration rates for ammonium vs. salinity in May 1992. Each point represents the mean from triplicate bottle treatments except for the 18 and $28 \%$ stations, which represent single measurements. Unless shown, the SE bars for the stations with replicate treatments were smaller than the size of the symbols.

ducted under both natural light and dark conditions to examine the effects of light on nitrogen cycling rates. As expected (Lipschultz et al. 1986), potential uptake rates for ammonium were significantly higher in bottles incubated in the light than in comparable bottles held in the dark (Figs. 4,5 ). Time-course observations indicated that rates of isotope dilution were typically constant over incubation intervals of up to $10 \mathrm{~h}$ and that the rates were substantially different between light and dark bottles incubated under oth-
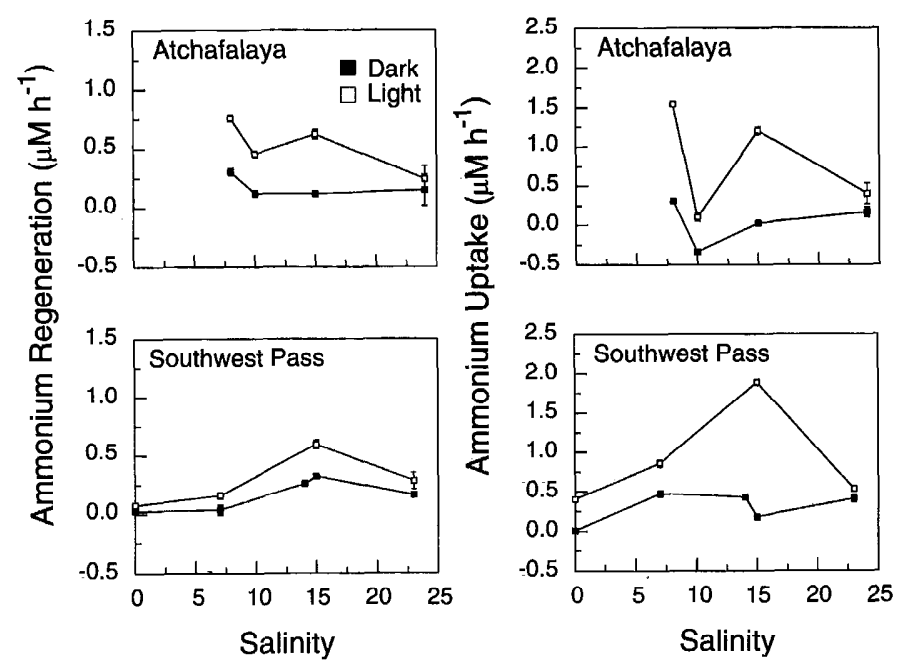

Fig. 4. Potential uptake and regeneration rates for ammonium vs. salinity for the Alchafalaya and Southwest Pass transects of the July 1993 cruise. Each point represents the mean from triplicate bottle treatments. Unless shown, the SE bars were smaller than the size of the symbols.

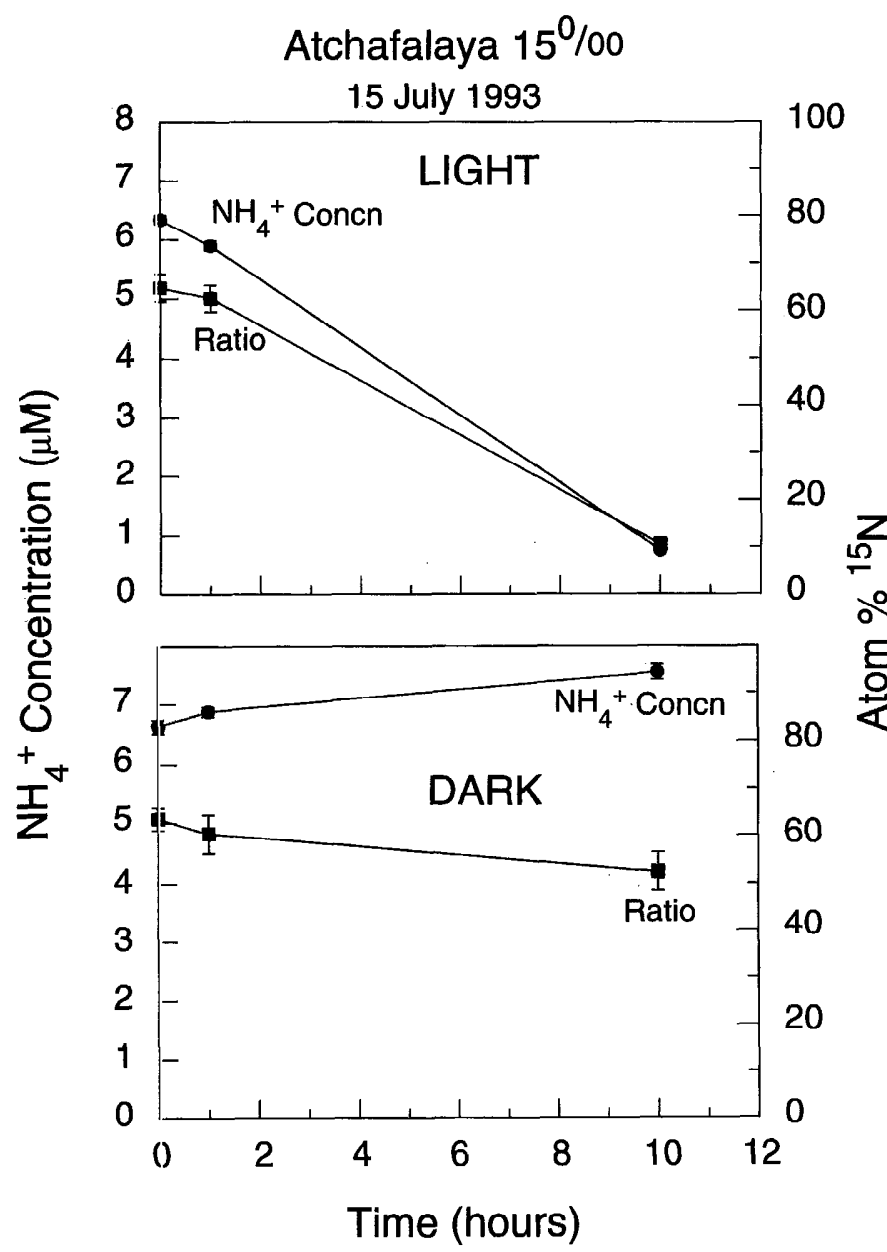

Fig. 5. Time-course patterns of concentrations and isotope ratios for ammonium after samples (from Atchafalaya transect $15 \%$ o station) wcre spiked with $4 \mu \mathrm{M}^{15} \mathrm{NH}_{4}{ }^{+}$and incubated under naturallight and dark conditions. Unless shown, the SE bars were smaller than the siz'e of the symbols.

erwise identical conditions (e.g. Fig. 5). In our experiments, potential uptake rates were $\sim 2-60$ times higher in light bottles than in dark bottles in the two transects. Similarly, ammonium regeneration rates were consistently higher in light bottles than in dark ones (Fig. 4). In the Southwest Pass transect, the light/dark regeneration rate ratios ranged from $\sim 2$ to 8 at the different sites vs. $2-6$ in the Atchafalaya transect.

Bacterial-addition experiments-The effects of added bacterial concentrates on nitrogen dynamics under natural light in the isotope-dilution experiments varied with site and season. In May, the addition of these particles had negligible effects on ammonium regeneration rates at the "Head of Passes" station (0\%o) but increased rates in direct proportion $(r=0.948)$ to bacterial numbers at the $18 \%$ o station (Fig. 6). Bacterial additions also increased regeneration rates at the $28 \%$ station, but the slope and correlation coefficient of the relationship between bacterial number and regeneration rates were lower than those for the $18 \%$ station (Fig. 6). In 


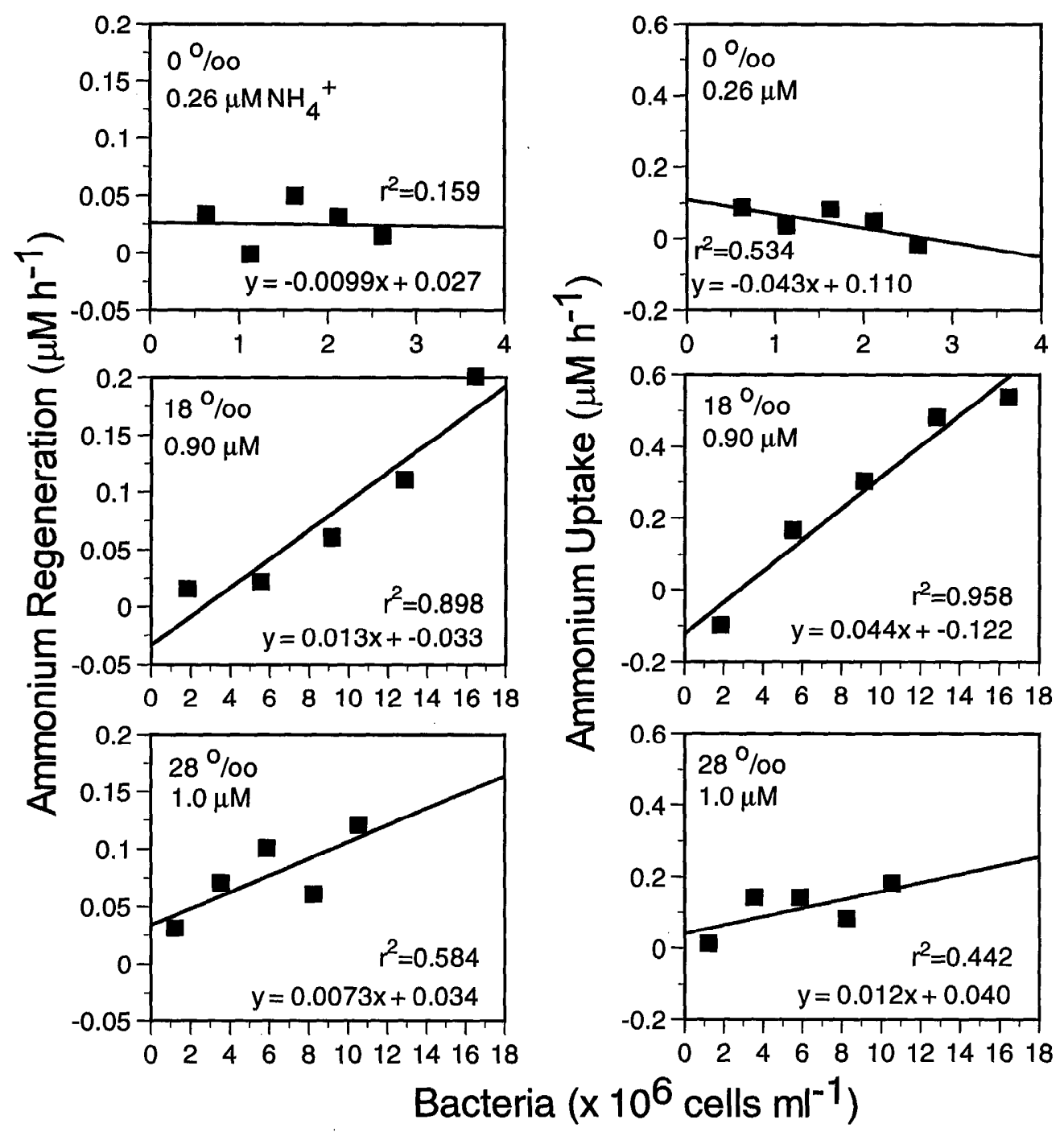

Fig. 6. Effects of added bacterial-sized particles on regeneration and potential uptake rates at three stations in May 1992. Incubation intervals for the treatments from the 0,18 , and $28 \%$ samples were $4.3,5.3$, and $5.7 \mathrm{~h}$.

July, net removal rates for ammonium were highest at the $8 \%$ station in the Atchafalaya transect and increased with increased concentrations of bacterial-sized particles (data not shown). Even in the treatment without bacterial additions, ammonium concentrations were reduced from 4.5 to $\sim 0.2$ $\mu \mathrm{M}$ during a 4.5 -h incubation interval. Ammonium regeneration rates could not be calculated at this site because ammonium levels in all treatments were too low for either ammonium concentrations or isotope ratios to be accurately measured after the first interval. At the $15 \%$ o station offshore from Atchafalaya Bay, net removal rates of ammonium were high and a significant correlation $(r=0.990)$ was observed for both ammonium regeneration and potential uptake rates with increasing abundances of added bacteria (Fig. 7).

The addition of bacterial concentrates had a less pronounced effect on uptake or regeneration rates of ammonium at the two stations examined in the Southwest Pass transect than in the Atchafalaya transect. Higher net removal rates were observed at the low salinity (7\%o) than at the high salinity $(23 \%$ ) station, but interestingly the highest net removal rates for ammonium during the first interval were in the treatments without bacterial additions at both stations. Addition of bacteria slightly reduced ammonium regeneration rates at the $7 \%$ o station but increased regeneration rates at the 23\%o station (Fig. 7). The cell-specific regeneration rates and correlation coefficients were both lower at the Southwest Pass 23\%o station than at the Atchafalaya 15\%o station even though bacterial numbers were similar in the concentrates from the two stations (Fig. 7).

Ammonium regeneration rates were usually lower in controls (i.e. no added particles) in the bacterial concentration experiments (Figs. 6, 7) than in comparable natural light experiments on waters that were processed soon after sampling (Figs. 3, 4). The rates resembled regeneration results from the dark incubations on the waters processed soon after sampling. This result may reflect the effect of storing the water used for the bacterial-concentration experiments out of sunlight during the period of particle isolation $(\sim 1-3 \mathrm{~h})$ be- 


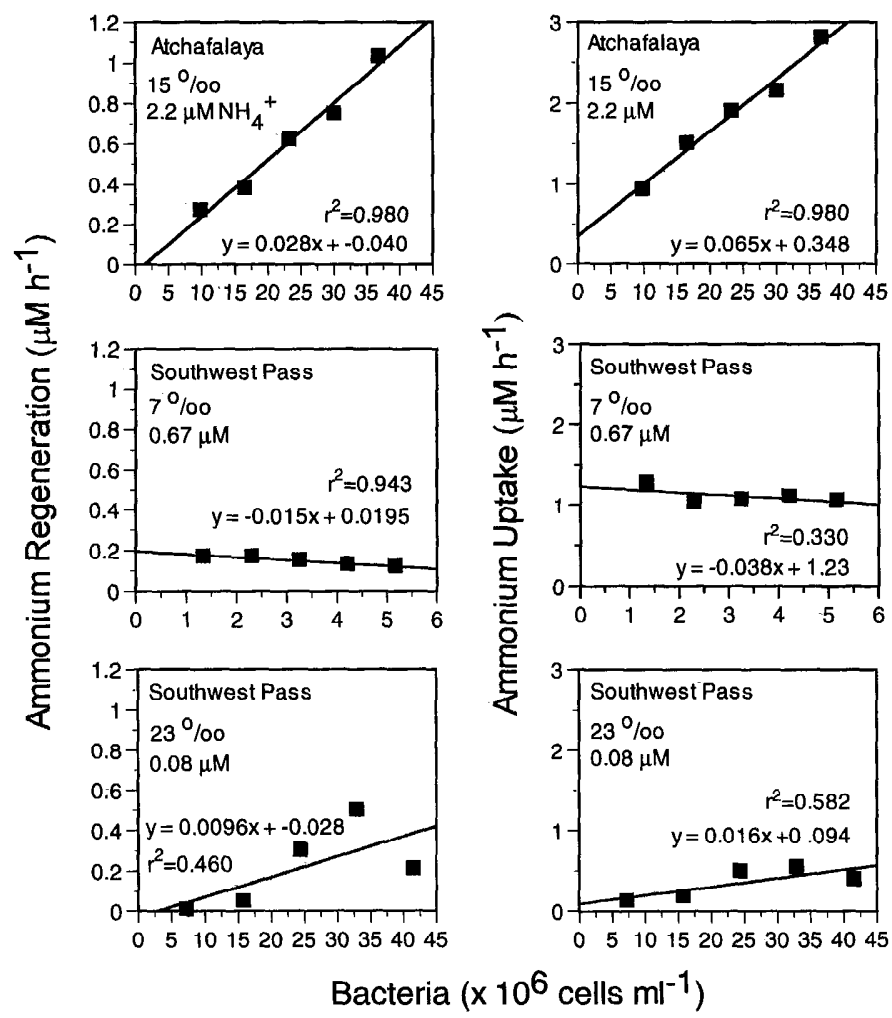

Fig. 7. Effects of added bacterial-sized particles on potential uptake and regeneration rates at three stations from the July 1993 cruise. Incubation intervals for the treatments from the 15,7 , and $23 \%$ o samples were $2.25,2.65$, and $2.5 \mathrm{~h}$.

fore the isotope dilution experiments were begun on these treatments.

\section{Discussion}

Regional nitrogen dynamics-In agreement with previous studies of nitrogen cycling rates in the Mississippi River plume (Cotner and Gardner 1993; Gardner et al. 1994), our natural light results showed highest rates in midsalinity regions of the plume where phytoplankton (Lohrenz et al. 1990) and bacterial (Chin-Leo and Benner 1992; Cotner and Gardner 1993) abundances and production rates were highest. Peaks in recycling rates relative to salinity patterns were observed on both cruises, but they occurred at different salinities $-28 \%$ in spring vs. $15 \%$ in the southwest transect in the July cruise. These differences in salinities for peak recycling rates were likely caused by differences in the abundances and compositions of phytoplankton and other organisms that, in turn, were related to regional and temporal differences in abiotic turbidity and nutrient concentration originating from the river at the different sites. The peaks in regeneration rates and other heterotrophic processes in the midsalinity regions of the plume, where uptake rates were also highest, are consistent with the idea that internal recycling is a major supplier of nutrients supporting primary production in these regions (Cotner and Gardner 1993; Fahnenstiel et al. 1995).

The observed nitrogen turnover rates were comparable to rates previously reported for coastal environments. However, our peak values for potential uptake $\left(1.9 \mu \mathrm{M} \mathrm{h}^{-1}\right)$ and regeneration $\left(0.75 \mu \mathrm{M} \mathrm{h}^{-1}\right)$ rates for ammonium in natural light are high relative to other values reported for coastal systems. Ammonium regeneration rates in the Delaware River ranged from 0.02 to $0.62 \mu \mathrm{M} \mathrm{h}^{-1}$ (Lipshultz et al. 1986) as compared to $0.02-0.35 \mu \mathrm{M} \mathrm{h}^{-1}$ in Georgia coastal waters (Hanson et al. 1990). Seasonal community ammonium regeneration rates ranged from $\sim 0$ to $0.2 \mu \mathrm{M} \mathrm{h}^{-1}$ (or up to $0.45 \mu \mathrm{M} \mathrm{h}^{-1}$ in the presence of zebra mussels) in a eutrophic region of Saginaw Bay, Lake Huron (Gardner et al. 1995b). A summary of published data for coastal regions gave ammonium regeneration rates of $0-0.26 \mu \mathrm{M} \mathrm{h}^{-1}$ and uptake values of $0.01-0.22 \mu \mathrm{M} \mathrm{h}^{-1}$ (Selmer 1988).

Similarly, summer phytoplankton growth rates in the Mississippi River plume, as measured by two independent techniques, were very high-taxon-specific growth rates reached as high as $3 \mathrm{~d}^{-1}$. These growth rates are among the highest reported for marine phytoplankton and approach or exceed maximum rates reported even under optimal culture conditions (Fahnenstiel et al. 1995). Nutrient-enhanced total-community phytoplankton growth rates ranged from 0.5 to 2.1 $\mathrm{d}^{-1}$ in May and October and were highest at high irradiance levels (Strom and Strom 1996). The combination of high nutrient inputs from the Mississippi and Atchafalaya Rivers with warm temperatures and high light intensities apparently provide optimal conditions for phytoplankton growth, microbial food web activity, and high rates of nutrient cycling in plume surface waters.

The bacterial concentration experiments provided information about bacterial-specific nitrogen cycling rates and allowed us to estimate the importance of bacteria relative to other heterotrophs in nitrogen cycling at the different stations. In the May experiments, ammonium regeneration and uptake rates increased progressively with increased concentrations of bacterial-sized particles at salinities of 18 and $28 \%$. However, the ratio of bacterial cell-specific regeneration to uptake rates (i.e. the ratio of regeneration rate slope to potential uptake slope at the same stations; Fig. 6) was higher in the $28 \%$ o water $(0.53)$ than in the $18 \%$ o water $(0.30)$. The addition of particle concentrates did not affect regeneration rates in river outflow water from the Head of Passes station $(0 \%)$ and slightly decreased $(P<0.1)$ uptake rates. The slight decrease in uptake rates can reasonably be attributed to dilution of the unfiltered water sample with the particle concentrate that constituted from 0 to $20 \mathrm{ml}$ of the final 60-ml trea.tment.

In July, the addition of these particles to unfiltered water increased nitrogen turnover rates in the Atchafalaya transect stations but had less pronounced effects at the two stations examined in the Southwest Pass transect. Again, the bacterial cell-specific ratio of regeneration to uptake was higher at the high-salinity $(23 \%$ ) station $(0.60)$ than at the $15 \%$ o station (0.43). The difference in ratios may indicate that bacterial substrates had a lower $\mathrm{C}: \mathrm{N}$ ratio at the offshore stations than at the midsalinity stations or that grazers were more important relative to the bacteria in ammonium regeneration at the offshore stations. Alternatively, uptake rates may have been increased more by the presence of small cyanobacteria in the bacterial concentrates at the midsalinity Atchafalaya station 
than at the higher salinity Southwest Pass station. Although not quantified, cyanobacteria were observed to be more abundant in the bacterial-sized particle concentrate isolated from the $15 \%$ o Atchafalaya station than in those isolated from the Southwest Pass stations.

Comparison of ammonium regeneration rates-Our results clearly show that ammonium regeneration rates, as well as potential uptake rates, were higher in natural-light treatments than in otherwise identical dark treatments in July 1993. Likewise, rates from dark incubations in February 1991 (Cotner and Gardner 1993) were much lower than rates from natural-light incubations at comparable temperatures in May 1992. Direct comparisons of ammonium regeneration rates in light and dark incubations of Delaware River water did not show consistent light effects, but in cases where standard deviations did not overlap, the rates were usually (9 of 11 comparisons) higher in the light than in the dark (see figure 9 of Lipschultz et al. 1986). Although community isotope-dilution experiments do not reveal trophic interactions responsible for light-dark differences, light effects are expected to be less direct for regeneration than for uptake of ammonium because most heterotrophic processes do not require light for energy.

Part of the observed light-driven increases in ammonium regeneration that we observed may have been experimentally caused by the simultaneous active uptake of both isotopic forms of ammonium and passive release of nonionic ammonia (with natural isotopic abundance) by phytoplankton (Hoch et al. 1992). However, this isotopic fractionation would likely be small relative to measured recycling rates in isotope-dilution experiments with added ammonium. A part of the differences in ammonium regeneration between light and dark treatments may have been caused by phytoplankton-mediated breakdown of urea (Tamminen and Irmisch 1996). Urea was hypothesized to be a potentially important substrate for ammonium regeneration in the Mississippi River plume, based on the ratio of nitrogen mineralization rates to dissolved inorganic carbon production rates (Pakulski et al. 1995).

The relatively high levels $(4 \mu \mathrm{M})$ of ammonium added for the isotope dilution experiments also may have experimentally enhanced differences in heterotrophic ammonium regeneration rates between light and dark bottles. Increases in phytoplankton production rates caused by the addition of ammonium can potentially enhance DON release and remineralization rates (Selmer 1988). Bacterial growth rates increased more in the light than in the dark in the presence of added ammonium and high-molecular-weight dissolved organic carbon (Gardner et al. 1996). However, the regional differences that we observed in ammonium uptake and regeneration rates, as well as the general agreement of our ammonium regeneration rate data with other measurements of nitrogen recycling rates in coastal regions (see discussion above), suggest that our ammonium additions did not necessarily always stimulate recycling rates. Interestingly, the differences between light and dark regeneration rates (Fig. 4) were greatest in the Atchafalaya transect at stations where ambient ammonium concentrations were $>2 \mu \mathrm{M}$ before ${ }^{15} \mathrm{NH}_{4}{ }^{+}$additions (Fig. 2). Studies in Lake Michigan with tracer-level additions of ${ }^{15} \mathrm{NH}_{4}{ }^{+}$showed ratios between light and dark regeneration rates comparable to those observed in this study, even though actual rates were lower (H. Bootsma pers. comm.). Direct comparisons of regeneration rate measurements with high- and low-level additions of ${ }^{15} \mathrm{NH}_{4}{ }^{+}$on common samples are needed to assess the exact effects of different levels of ammonium additions on light vs. dark regeneration rate results.

Regardless of whether absolute regeneration rates were affected by the ammonium additions, our data clearly show substantial and consistent enhancement of ammonium regeneration rates under natural light over those observed in dark incubations. We think that a reasonable explanation for the enhancement is a relatively direct coupling between autotrophic and heterotrophic nutrient cycling processes within the time scale of the experimental incubations (a few hours). This coupling could be mediated by increased growth rates and grazing of small phytoplankton in the light or by lightinduced production of labile organic nitrogen that is rapidly metabolized by the microbial food web.

Microzooplankton grazing is the major process responsible for removing small, nondiatom species of phytoplankton in the plume, whereas both sedimentation (Fahnenstiel et al. 1995) and grazing (Strom and Strom 1996) are major loss processes for diatoms. The grazing process could cause light-dark differences in regeneration rates if the grazers respond rapidly to the high phytoplankton growth rates that have been observed in these warm, nutrient-rich plume waters (Fahnenstiel et al. 1995; Strom and Strom 1996).

Photosynthesis could also cause light-dark differences in bacterially mediated regeneration rates. Direct exudation by phytoplankton (Cole et al. 1982) and "sloppy feeding" by microzooplanktonic or protozoan grazers (Strom and Strom 1996) can provide fresh sources of DON that can be incorporated into the microbial food web. Dissolved organic carbon excretion rates by phytoplankton were proportional to irradiance levels (Zlotnik and Dubinsky 1989). Direct mineralization of organic nitrogen by bacteria is a seasonally important process in Japanese lakes (Haga et al. 1995) and seems to occur in the Mississippi River plume (Cotner and Gardner 1993). The direct importance of dissolved free or combined amino acids (that have a low $\mathrm{C}: \mathrm{N}$ ratio) to bacterial dynamics and ammonium regeneration has been shown in a variety of coastal and other aquatic environments (e.g. Keil and Kirchman 1991). The dynamics of these labile compounds likely depend more on supply rates than on accumulated concentrations in the water.

The increased rates of ammonium regeneration with increased added bacterial concentrations that we observed at several stations may indicate that bacteria themselves directly regenerate ammonium (Cotner and Gardner 1993) or may reflect the increased food supply made available to the bacterial grazers that would in turn cause regeneration rates to increase. The cell-specific ratios of regeneration to uptake rates increased at offshore stations, indicating that the contribution of bacterial-sized particles to ammonium regeneration or uptake varied regionally.

Bacterial incorporation of DOM with a high $\mathrm{C}: \mathrm{N}$ ratio (Amon and Benner 1994) provides energy for bacterial respiration and allows much of the labile organic nitrogen as- 
similated by bacteria to be incorporated into biomass rather than excreted as ammonium (Gardner et al. 1996). If labile DOC with a high $C: N$ ratio is available in the water or produced in the light by phytoplankton, most available amino acids would likely be incorporated into bacterial biomass rather than serve as a carbon source for respiration. Under these conditions, excretion by bacterial grazers would likely be the dominant ammonium regeneration process.

\section{Conclusions}

Our studies in the Mississippi River plume of the northern Gulf of Mexico indicate that ammonium regeneration rates in surface waters, as mcasured by isotope-dilution experiments with the Blackburn model, were comparable to or higher than those reported for other coastal systems. The rates were consistently and at times substantially higher under natural light conditions than in the dark. These data imply a close coupling between autotrophic and heterotrophic food-web organisms and nutrient regeneration in Mississippi River plume surface waters. Explanations for this light-dark difference are enhanced phytoplankton growth with associated grazing by microzooplankton or enhanced labile DON release by phytoplankton that in turn causes bacterial uptake and microbial processes to increase. Ammonium regeneration rates would then be elevated by either bacteria or their grazers. It is also possible that phytoplankton-mediated enzymatic breakdown of urea produced by heterotrophic organisms could be responsible for some of the light-dark differences in ammonium regeneration rates. The apparently close coupling between autotrophic and heterotrophic processes over short time scales emphasizes the importance of further understanding microbial food-web dynamics, particularly as they relate to nutrient cycling processes in nearsurface coastal waters.

\section{References}

AMON, R. M. W., AND R. BEnNER. 1994. Major role for highmolecular-weight dissolved organic matter in the marine carbon cycle. Nature 369: 549-552.

Benner, R., J. D. Pakulski, M. McCarthy, J. I. Hedges, and P. G. HATCHER. 1992. Bulk chemical characteristics of dissolved organic matter in the ocean. Science 255: 1561-1564.

BlackBuRn, H. T. 1979. Method for measuring rates of $\mathrm{NH}_{4}{ }^{+}$turnover in anoxic marine sediments, using a ${ }^{15} \mathrm{~N}^{-\mathrm{NH}_{4}}{ }^{+}$dilution technique. Appl. Environ. Microbiol. 37: 760-765.

Bronk, D. A., P. M. Glibert, AND B. B. Ward. 1994. Nitrogen uptake, dissolved organic nitrogen release, and new production. Science 265: 1843-1846.

Carlsson, P., E. Granéli, P. Tester, and L. Boni. 1995. Influences of riverine humic substances on bacteria, protozoa, phytoplankton, and copepods in a coastal plankton community. Mar. Ecol. Prog. Ser. 127: 213-221.

Chin-LeO, G., AND R. BenNeR. 1992. Enhanced bacterioplankton production at intermediate salinities in the Mississippi River plume. Mar. Ecol. Prog. Ser. 87: 87-103.

Coffin, R. B., J. P. Connolly, And P. S. Harris. 1994. Availability of dissolved organic carbon to bacterioplankton examined by oxygen utilization. Mar. Ecol. Prog. Ser. 101: 9-22.

Cole, J. J., G. E. Likens, And D. L. Strayer. 1982. Photosynthetically produced dissolved organic carbon: An important carbon source for planktonic bacteria. Limnol. Oceanogr. 27: 1080-1090.

COTNER, J. B., AND W. S. GARDNER. 1993. Heterotrophic bacterial mediation of ammonium and dissolved free amino acid fluxes in the Mississippi River plume. Mar. Ecol. Prog. Ser. 93: 7587.

FaHnenstie.l, G. L., AND OTHERS. 1995. Taxon-specific growth and loss rates for dominant phytoplankton populations from the northern Gulf of Mexico. Mar. Ecol. Prog. Ser. 117: 229-239.

FINLAY, S., AND OTHERS. 1991. Weak coupling of bacterial and algal production in a heterotrophic ecosystem: The Hudson River estuary. Limnol. Oceanogr. 36: 268-278.

GARDNER, W. S., R. BENNER, R. M. W. AMON, AND OTHERS. 1996. Effects of high molecular weight dissolved organic matter on nitrogen dynamics in the Mississippi River plume. Mar. Ecol. Prog. Ser. 133: 287-297.

- - - E. Chin-LeO, AND OTHERS. 1994. Mineralization of organic material and bacterial dynamics in Mississippi River plume water. Estuaries 17: 816-828.

$\longrightarrow$, H. A. Bootsma, C. Evans, AND P. A. ST. John. $1995 a$. Improved chromatographic analysis of ${ }^{15} \mathrm{~N}:{ }^{14} \mathrm{~N}$ ratios in ammonium or nitrate for isotope addition experiments. Mar. Chem. 48: 271-282.

- J. F. CAVOLETTO, AND OTHERs. 1995b. Effects of the zebra mussel, Dreissena polymorpha, on community nitrogen dynamics in Saginaw Bay, Lake Huron. J. Great Lakes Res. 21: 529-544.

—, J. B. COTNER, JR., AND L. R. HERCHE. 1993. Chromatographic measurement of nitrogen mineralization rates in marine coastal waters with ${ }^{15}$ N. Mar. Ecol. Prog. Ser. 93: 65-73.

- , ANE P. A. ST. JoHN. 1991. High-performance liquid chromatographic method to measure ammonium ion and primary amines in seawater. Anal. Chem. 63: 537-540.

Hanson, R. B., C. Y. Robertson, J. A. Yoder, P. G. Verity, AND S. S. BishOP. 1990. Nitrogen recycling in coastal waters of southcastern U.S. J. Mar. Res. 48: 641-660.

HaGa, H., T. NaGata, and M. SaKamoto. 1995. Size-fractionated $\mathrm{NH}_{4}{ }^{+}$regeneration in the pelagic environments of two mesotrophic lakes. Limnol. Oceanogr. 40: 1091-1099.

Hobbie, J. E., R. J. DALEY, AND S. JASPER. 1977. Use of Nuclepore filters for counting bacteria by fluorescence microscopy. Appl. Environ. Microbiol. 33: 1225-1228.

Hoch, M. P., M. L. FoGEL, AND D. L. KIRChMAN. 1992. Isotope fractionation associated with ammonium uptake by a marine bacterium. Limnol. Oceanogr. 37: 1447-1459.

KEIL, R. G., AND D. L. KIRCHMAN. 1991. Contribution of dissolved free amino acids and ammonium to the nitrogen requirements of heterotrophic bacterioplankton. Mar. Ecol. Prog. Ser. 73: 110.

LipsChultz, F., S. C. Wofsy, AND L. E. Fox. 1986. Nitrogen metabolism of the eutrophic Delaware River ecosystem. Limnol. Oceanogr. 31: 701-716.

Lohrenz, S. E., M. L. DAgG, And T. E. Whitledge. 1990. Enhanced primary production at the plume/oceanic interface of the Mississippi River. Cont. Shelf Res. 10: 639-664.

Miller, C. A., D. L. Penry, And P. M. Glibert. 1995. The impact of trophic interactions on rates of nitrogen regeneration and grazing in Chesapeake Bay. Limnol. Oceanogr. 40: 1005-1011.

Pakulski, J. D., R. Benner, R. Amon, B. Eadie, ANd T. WhitLEDGE. 1995. Community metabolism and nutrient cycling in the Mississippi River plume: Evidence for intense nitrification at intermediate salinities. Mar. Ecol. Prog. Ser. 117: 207-218.

Selmer, J. S. 1988. Ammonium regeneration in eutrophicated coastal waters of Sweden. Mar. Ecol. Prog. Ser. 44: 265273. 
Strom, S. L., AND M. W. STrom. 1996. Microplankton growth, grazing, and community structure in the northern Gulf of Mexico. Mar. Ecol. Prog. Ser. 130: 229-240.

TAMMINEN, T., AND A. IRMISCH. 1996. Urea uptake kinetics of a midsummer planktonic community on the SW coast of Finland. Mar. Ecol. Prog. Ser. 130: 201-211.
Zlotnik, I., AND Z. DubinsKy. 1989. The effect of light and temperature on DOC excretion by phytoplankton. Limnol. Oceanogr. 34: 831-839.

Submitted: 17 February 1996 Accepted: 12 July 1996 Amended: 12 November 1996 